\section{EFFICIENCY OF TRADITIONAL DNA EXTRACTION METHOD IN PCR DETECTION OF PORCINE DNA IN MEAT MIXTURES}

\author{
Zaliha Suadia, Lesley Maurice Bilunga*, Kasing Apuna, Aida Azrina \\ Azmib
}

aDepartment of Molecular Biology, Faculty of Science and Resource Technology, Universiti Malaysia Sarawak, 94300, Kota Samarahan, Sarawak, Malaysia bHalal Products Research Institute, Universiti Putra Malaysia, 43400 UPM Serdang, Malaysia
Article history

Received

6 February 2020

Received in revised form

2 July 2020

Accepted

15 July 2020

Published online

27 August 2020

\section{*Corresponding author} mblesley@unimas.my

\section{Graphical abstract}

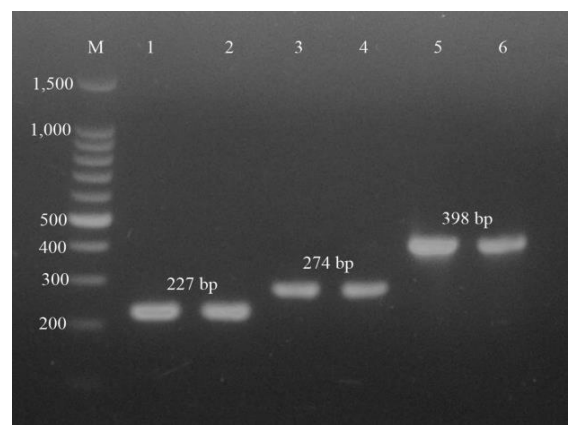

PCR product sizes of mitochondrial DNA cytochrome b gene for the investigated species.

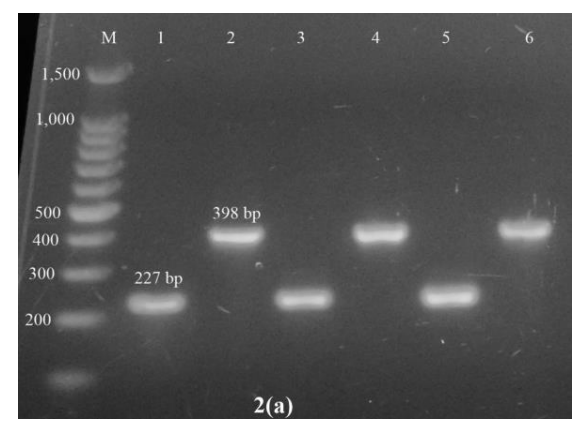

Species-specific simplex-PCR of cytochrome $b$ gene fragments of chicken (227 bp) and pork (398 bp) from raw meat mixtures extracted using commercial extraction kit.

\begin{abstract}
Through the advancement of biotechnology, DNA-based methods are the most effective techniques in species identification, as they are rapid and have higher stability in harsh conditions compared to protein-based methods. This study was conducted to determine the efficiency of the traditional DNA extraction method, phenol/chloroform/isoamyl alcohol (PCIA), and comparing it with the commercially available kit by evaluating the purity, concentration, and suitability for amplification of porcine DNA in raw chicken and beef mixtures. The quantity and quality of the DNA extracts were assessed using a UV-Vis spectrophotometer. Polymerase chain reaction (PCR) was performed using species-specific primers targeting mitochondrial DNA cytochrome b (cyt b) gene of chicken (227-bp), beef (274-bp), and pork (398-bp), to confirm the template usability and quality of the DNA extracts. High DNA concentrations and purity were obtained from meat samples extracted using the PCIA method. The visualization of pork DNA on $2 \%$ agarose gel was able to detect pork contamination in raw meat mixtures up to minute proportion (1\%). The existence of pork in chicken and beef was indicated with the presence of a specific 398-bp DNA band. Thus, the PCIA method can be recommended as a cost-effective and an excellent alternative to more expensive extraction kits in detecting pork DNA in raw meat mixtures.
\end{abstract}

Keywords: Meat adulteration, PCIA extraction method, porcine DNA, PCR, cytochrome b

\begin{abstract}
Abstrak
Melalui kemajuan bioteknologi, kaedah berasaskan DNA adalah teknik yang paling berkesan dalam pengenalpastian spesies, kerana ia sangat cepat dan mempunyai kestabilan yang lebih tinggi dalam keadaan yang bertekanan tinggi berbanding dengan kaedah berasaskan protein. Kajian ini dijalankan untuk menentukan kecekapan kaedah pengekstrakan DNA tradisional, phenol/chloroform/isoamyl alcohol (PCIA) dan membandingkannya dengan kit komersil dengan menilai ketulenan, kepekatan dan kesesuaian untuk proses amplifikasi DNA khinzir dalam ayam dan daging lembu mentah. Kuantiti and kualiti ekstrak DNA dinilai menggunakan UV-VIS spectrophotometer. Polymerase chain reaction (PCR) dilakukan dengan menggunakan species specific primers yang menyasarkan mitokondria DNA cytochrome $b$ gen ayam, daging lembu dan daging khinzir, untuk mengesahkan kesesuaian template dan kualiti ekstrak DNA. Kepekatan dan ketulenan yang tinggi diperolehi daripada sampel yang diekstrak menggunakan kaedah PCIA. Visualisasi DNA khinzir menggunakan gel agarose $2 \%$ dapat mengesan pencemaran daging khinzir pada campuran daging mentah
\end{abstract}




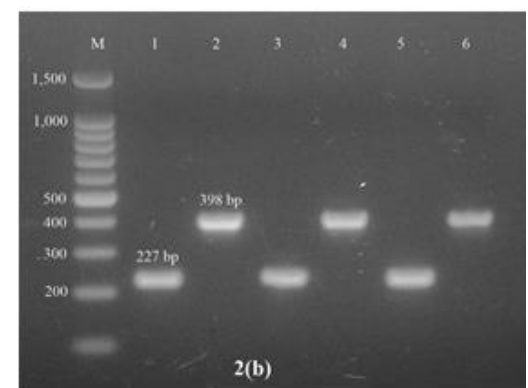

Species-specific simplex-PCR of cytochrome $b$ gene fragments of chicken (227 bp) and pork (398 bp) from raw meat mixtures extracted using the PCIA method. hingga pada takat $1 \%$. Kewujudan DNA khinzir dalam ayam dan daging lembu ditunjukkan dengan kehadiran band DNA yang khusus 398-bp. Oleh itu, kaedah PCIA boleh disyorkan sebagai kaedah alternatif yang sesuai dan kos efektif berbanding kit pengekstrakan yang lebih mahal dalam mengesan DNA daging khinzir dalam campuran daging mentah.

Kata kunci: Pencemaran daging, kaedah ekstraksi PCIA, DNA khinzir, PCR, sitokrom b

(c) 2020 Penerbit UTM Press. All rights reserved

\subsection{INTRODUCTION}

Due to the breath-taking development of technology and diversified global sources for food processing and production, varieties of food products from primary meats to processed goods in various brands are readily available in the market nowadays to meet consumer demands. The rapid economic and population growths in Malaysia over the last decades have fuelled the massive increase in demand-driven consumption for food of animal origin. The trend in consumption over the last years showed that there had been steady increases in the demand for meats in Malaysia.

Based on the Malaysian National Agro-food Policy 2011-2020 (NAP), the demand and production for meat are expected to increase. The demand is expected to increase from 1.4 million metric tons in 2010 to 1.8 million metric tons in 2020 with a growth of $2.4 \%$ per annum while meat production is forecast to increase from 1.6 million metric tons to 2.1 million metric tons respectively with a growth of $2.7 \%$ per annum in the same period [1]. Meat has become an essential component of the human diet as there are growing preferences towards meat as a source of protein.

Nowadays, consumers are very concerned about issues related to food, especially on adulteration. There are increasing concerns among consumers as well as food quality and safety regulatory agencies regarding adulteration of meats with that of other usually less expensive species [2]. Besides economic, there are religious, cultural, and health and safety issues associated with the sale of raw, cooked, or processed meats that are accidentally or intentionally adulterated with other meats [3].

Through the advance of biotechnology and research, numerous identification methods for meat species identification have been developed, and todate, two main methods are recognized for meat species detection and identification in food, which are protein- and DNA-based methods $[4,5]$. Proteinbased methods, however, have limitations in the detection of meat species from cooked or heat- treated food products since proteins can be denatured during processing $[6,7,8]$. DNA-based methods such as Polymerase Chain Reaction (PCR) are the most precise and sensitive techniques for species identification, and they are comparatively quick compared to protein-based methods $[9,10]$.

Nevertheless, the prerequisite to a successful identification of species by PCR-based techniques is high-quality DNA; therefore, the selection of an appropriate DNA extraction method plays a crucial role in this regard [11]. It is indisputable that commercial extraction kits provide direct, faster, safer, rapid, and better efficiency in contrast with conventional methods such as phenol/chloroform method for extracting DNA from animal products. However, they are more expensive compared to the latter [12, 13]. Conventional methods also have been said to be time-consuming and may introduce inhibitors due to the use of certain chemicals during extraction, such as chloroform. It is crucial that in order to acquire high purity, amount, and intact DNA, the presence of inhibitors in food matrices must be eliminated prior to downstream applications [14].

In this paper, efficiency of the conventional phenol/chloroform/isoamyl alcohol (PCIA) extraction method as well as the commercially available extraction kit in PCR detection of chicken, beef, and pork in raw meat mixtures was compared by evaluating the yield and purity of DNA obtained. PCR amplification was performed using species-specific primers targeting the mitochondrial DNA cytochrome $b$ (cyt b) gene to confirm the quality of the DNA extracts and the template usability.

\subsection{METHODOLOGY}

\subsection{Samples Preparation to Evaluate the PCR Sensitivity}

Fresh raw meat muscles (pork, beef, and chicken) were randomly purchased from local wet markets around Kuching, Sarawak. The samples were cut into 
small pieces and stored frozen at $-20^{\circ} \mathrm{C}$ until used to prevent enzymatic degradation of DNA.

Beef samples were contaminated with pork in the ratios of 100:0, 50:50, 90:10, and 99:1\% (beef: pork). Each combination of meats were prepared in a total weight of $200 \mathrm{mg}$. These ratios were also applied for chicken samples (chicken: pork).

\subsection{Isolation of DNA}

Approximately $200 \mathrm{mg}$ of minced meat mixtures were lysed in a buffer solution containing Tris- $\mathrm{HCl}, \mathrm{pH} 7.5$, EDTA, $\mathrm{NaCl}$, and SDS with concentrations stated in Table 1. Proteinase K $(10 \mathrm{mg} / \mathrm{ml})$ was also added, and the mixtures were incubated overnight at $56^{\circ} \mathrm{C}$.

Table 1 Concentrations and reagents of the lysis buffer

\begin{tabular}{cc}
\hline Reagent & Concentration \\
\hline Tris- $\mathrm{HCl}, \mathrm{pH} 7.5$ & $10 \mathrm{mM}$ \\
\hline EDTA & $10 \mathrm{mM}$ \\
\hline $\mathrm{NaCl}$ & $50 \mathrm{mM}$ \\
\hline $\mathrm{SDS}$ & $\mathbf{2 0 \%}$ \\
\hline
\end{tabular}

The DNA solutions were extracted with $500 \mu \mathrm{l}$ of PCIA (25:24:1). The solutions were then vortexed for $15 \mathrm{~s}$ and centrifuged at 13,000 rpm for $5 \mathrm{~min}$. The aqueous phase was transferred to a fresh microcentrifuge tube, and $500 \mu \mathrm{l}$ of PCIA (25:24:1) was again added. The solutions were again vortexed for $15 \mathrm{~s}$ and centrifuged at 13,000 rpm for $5 \mathrm{~min}$. The aqueous phase was transferred to a fresh microcentrifuge tube.

Absolute alcohol (1 ml) was added and mixed by inverting the tube. The solution was placed in $4 \circ \mathrm{C}$ for at least $30 \mathrm{~min}$ and then centrifuged for $20 \mathrm{~min}$ at $13,000 \mathrm{rpm}$. The DNA was recovered by decanting the supernatant and inverting the tubes on absorbent paper. After eliminating waste alcohol, DNA was solubilized by adding $60 \mu \mathrm{l}$ of Tris-EDTA buffer (TE), mixed and incubated at $56^{\circ} \mathrm{C}$ overnight.

DNA was also extracted using a commercially available DNA extraction kit, and isolated according to the manufacturer's protocol.

The purity and concentration of extracted DNA samples were determined using DR 6000'M UV-Vis spectrophotometer (Hach). The DNA samples with $O D_{260: 280}$ ratio in the range of 1.7 to 2.0 were considered good and were used for PCR amplification.

\subsection{PCR Protocol}

Four oligonucleotide primer sets (synthesized by Macrogen Inc. Korea) derived from the mitochondrial DNA cyt b gene sequences for the amplification of chicken, beef, and pork, as designed by Matsunaga et al. [15], were used for the PCR amplification. The primer sequences are as given in Table 2.

Table 2 Cytochrome b primer sequences

\begin{tabular}{ccc}
\hline $\begin{array}{c}\text { Primer } \\
\text { Name }\end{array}$ & Sequences (5' -3') & $\begin{array}{c}\text { No. of } \\
\text { bases }\end{array}$ \\
\hline $\begin{array}{c}\text { Common } \\
\text { forward }\end{array}$ & $\begin{array}{c}\text { 5'-GAC CTC CCA GCT CCA } \\
\text { TCA AAC ATC TCA TCT TGA } \\
\text { TGA AA-3' }\end{array}$ & 38bp \\
\hline $\begin{array}{c}\text { Pig } \\
\text { Reverse }\end{array}$ & 5'-GCT GAT AGT AGA TTT GTG & $27 \mathrm{bp}$ \\
\hline $\begin{array}{c}\text { Cattle ACC GTA-3' } \\
\text { Reverse }\end{array}$ & 5'-CTA GAA AAG TGT AAG & $29 \mathrm{bp}$ \\
\hline $\begin{array}{c}\text { Chicken } \\
\text { Reverse }\end{array}$ & 5'-AAG ATA CAG ATG AAG & $27 \mathrm{bp}$ \\
\hline
\end{tabular}

Simplex PCR amplification was accomplished in a $25 \mu$ total volume containing 0.625U GoTaq Flexi DNA Polymerase (Promega, Madison, USA), $5 \mu$ of $5 \mathrm{X}$ GoTaq Flexi Buffer, $200 \mu \mathrm{M}$ each of dNTP, $1.5 \mathrm{mM}$ $\mathrm{MgCl}_{2}, 0.4 \mu \mathrm{M}$ primers and $1 \mu \mathrm{l}(30 \mathrm{ng} / \mu \mathrm{l})$ of total DNA in thermal cycler GeneAmp® PCR System 9700 (Applied Biosystems, Foster City, CA) and the cycling parameters were initial denaturation at $94^{\circ} \mathrm{C}$ for 3 min following 35 cycles of denaturation at $94^{\circ} \mathrm{C}$ for $30 \mathrm{~s}$, annealing at $60^{\circ} \mathrm{C}$ for $30 \mathrm{~s}$ and elongation at $72^{\circ} \mathrm{C}$ for $30 \mathrm{~s}$ and final elongation at $72^{\circ} \mathrm{C}$ for $3 \mathrm{~min}$.

Five $\mu$ l of the PCR products from each amplified product was electrophoresed along with a 100-bp DNA ladder marker (Promega) to confirm the targeted PCR amplification. The electrophoresis was performed on $2 \%$ agarose gel containing ethidium bromide $(0.5 \mu \mathrm{g} / \mathrm{ml})$ at constant $80 \mathrm{~V}$ for $60 \mathrm{~min}$ in $1 \mathrm{X}$ Tris-acetate EDTA (TAE) buffer. The bands in the gel were then visualized using PhotoDoc-It Imaging System (UVP)

\subsection{RESULTS AND DISCUSSION}

The concentrations and quality of the obtained DNA using conventional PCIA protocol and commercial DNA extraction kit are presented in Table 3. The results show that the highest concentration of DNA was obtained by the conventional PCIA extraction method. The purity (OD $260 / 280$ values) and concentrations of DNA from meat samples extracted using the PCIA extraction method ranged from 1.5 to 1.9, and $1,437.5$ to $5,285.0 \mathrm{ng} / \mu \mathrm{l}$, respectively. The purity and concentrations of DNA from meat samples extracted using commercial kit ranged from 1.3 to 2.2 , and 7.5 to $142.5 \mathrm{ng} / \mu \mathrm{l}$, respectively. Despite the low and high purity values of particular samples that were not within the ideal range, PCR amplifications 
were still carried out, and the results still produced well-developed, high-intensity bands.

Table 3 Concentrations and purity of the obtained DNA extracted using the conventional method

\begin{tabular}{|c|c|c|c|}
\hline $\begin{array}{l}\text { Extraction } \\
\text { Method }\end{array}$ & Contents & $\begin{array}{c}\text { Purity } \\
\left(O D_{260 / 280}\right)\end{array}$ & $\begin{array}{c}\text { Concentration } \\
\text { s } \\
(n g / \mu l)\end{array}$ \\
\hline \multirow{9}{*}{ PCIA } & $\begin{array}{l}100 \% \text { raw } \\
\text { chicken }\end{array}$ & 1.8 & $4,957.5$ \\
\hline & $\begin{array}{c}100 \% \text { raw } \\
\text { beef }\end{array}$ & 1.7 & $5,285.0$ \\
\hline & $\begin{array}{l}100 \% \text { raw } \\
\text { pork }\end{array}$ & 1.9 & $2,550.0$ \\
\hline & $\begin{array}{l}50 \% \text { pork in } \\
\text { chicken }\end{array}$ & 1.9 & $4,092.5$ \\
\hline & $\begin{array}{l}50 \% \text { pork in } \\
\text { beef }\end{array}$ & 1.7 & $1,437.5$ \\
\hline & $\begin{array}{l}10 \% \text { pork in } \\
\text { chicken }\end{array}$ & 1.8 & $4,610.0$ \\
\hline & $\begin{array}{l}10 \% \text { pork in } \\
\text { beef }\end{array}$ & 1.6 & $2,507.5$ \\
\hline & $\begin{array}{l}1 \% \text { pork in } \\
\text { chicken }\end{array}$ & 1.9 & $4,395.0$ \\
\hline & $\begin{array}{l}1 \% \text { pork in } \\
\text { beef }\end{array}$ & 1.5 & $1,485.0$ \\
\hline \multirow{9}{*}{$\begin{array}{l}\text { Commer } \\
\text { cial } \\
\text { extraction } \\
\text { kit }\end{array}$} & $\begin{array}{l}100 \% \text { raw } \\
\text { chicken }\end{array}$ & 1.8 & 117.5 \\
\hline & $\begin{array}{c}100 \% \text { raw } \\
\text { beef }\end{array}$ & 2.0 & 105.0 \\
\hline & $\begin{array}{l}100 \% \text { raw } \\
\text { pork }\end{array}$ & 1.7 & 77.5 \\
\hline & $\begin{array}{l}50 \% \text { pork in } \\
\text { chicken }\end{array}$ & 2.2 & 97.5 \\
\hline & $\begin{array}{c}50 \% \text { pork in } \\
\text { beef }\end{array}$ & 1.3 & 7.5 \\
\hline & $\begin{array}{l}10 \% \text { pork in } \\
\text { chicken }\end{array}$ & 2.2 & 142.5 \\
\hline & $\begin{array}{l}10 \% \text { pork in } \\
\text { beef }\end{array}$ & 1.7 & 57.5 \\
\hline & $\begin{array}{l}1 \% \text { pork in } \\
\text { chicken }\end{array}$ & 1.9 & 102.5 \\
\hline & $\begin{array}{l}1 \% \text { pork in } \\
\text { beef }\end{array}$ & 1.8 & 65.0 \\
\hline
\end{tabular}

The result is in agreement with the study done by Djurkin Kusec et al. [12], who obtained the highest concentration of DNA by conventional phenol/chloroform extraction method. They evaluated ten samples of traditional dry/fermented sausage produced from pork, salt, garlic, red paprika, and pepper using commercially available DNA extraction kits and standard PCIA extraction protocol. The highest concentration of DNA was obtained by conventional phenol extraction method $(2,123.5 \mathrm{ng} / \mathrm{\mu l}$ for samples homogenized using knife mill and $1,304.0 \mathrm{ng} / \mathrm{\mu l}$ for samples homogenized using mortar and pestle). However, the purity of DNA was rather unsatisfactory (1.149 for samples homogenized using knife mill and 1.137 for samples homogenized using mortar and pestle), implying a certain amount of phenol contamination. Among the commercial DNA extraction kits, DNeasy mericon Food Kit has produced the highest concentration and DNA purity (126.0 $\mathrm{ng} / \mathrm{\mu l}$ and 1.780 respectively for samples homogenized using knife mill; $164.0 \mathrm{ng} / \mathrm{\mu l}$ and 1.777 respectively for samples homogenized using mortar and pestle).

A study by Özşensoy \& Şahin [16], also concluded that the phenol/chloroform and commercial kit, gSYNC DNA Extraction Kit were found to be the most effective methods for obtaining high quantity DNA when they were comparing four different DNA isolation methods from several meat products such as sucuk, salami, sausage, braised meat, meatball, and pastrami. The methods included in their study were phenol/chloroform, DNA isolation kit, Cetyl Trimethyl Ammonium Bromide (CTAB), and Dodecyl Trimethyl Ammonium Bromide (DTAB).

Successful amplification of cyt b gene fragments in chicken, cattle, and pig was shown in Figure 1. Lane 1,3 , and 5 are the samples extracted using a commercial extraction kit, whereas lane 2, 4, and 6 are the samples extracted using the conventional PCIA extraction method. The PCR products showed species-specific DNA fragments of 227, 274, and 398 bp from chicken, cattle, and pig, respectively, thus confirm the product size in each species [15].

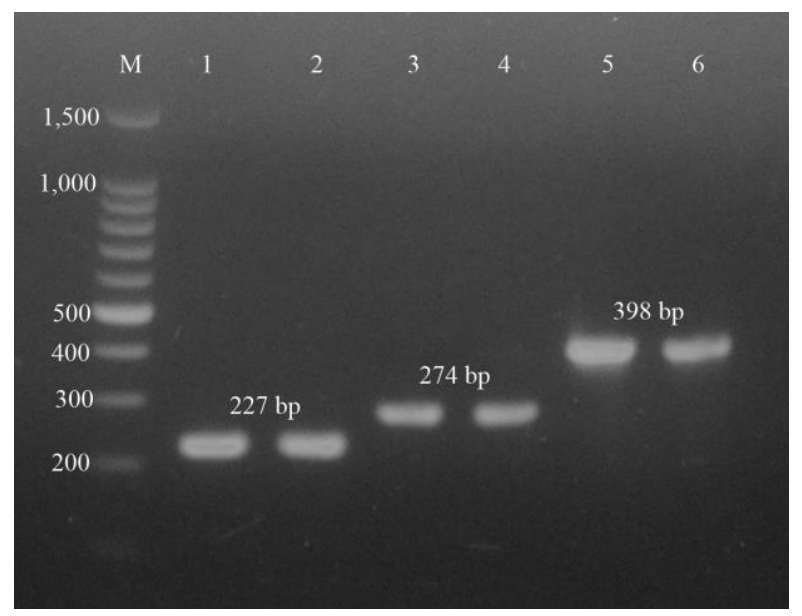

Figure 1 PCR product sizes of mitochondrial DNA cy $t \mathrm{~b}$ gene for the investigated species. Lane 1 and 2: chicken (227 bp); Lane 3 and 4: beef (274 bp); and Lane 5 and 6: pork (398 bp). Lane M, 100-bp DNA ladder

Pork contamination in chicken is shown in Figure 2, in which DNA fragments of $227 \mathrm{bp}$ (chicken) and 398 bp (pig) were detected. Lane 1 and 2 in both Figures 2 (a) and 2 (b) are chicken meat contaminated with $50 \%$ pork, lane 3 , and 4 with $10 \%$ pork contamination and lane 5 and 6 contaminated with $1 \%$ pork.

Pork contamination can be detected in this study, up to $1 \%$ in the mixture without showing any significant decrease in band intensity. 


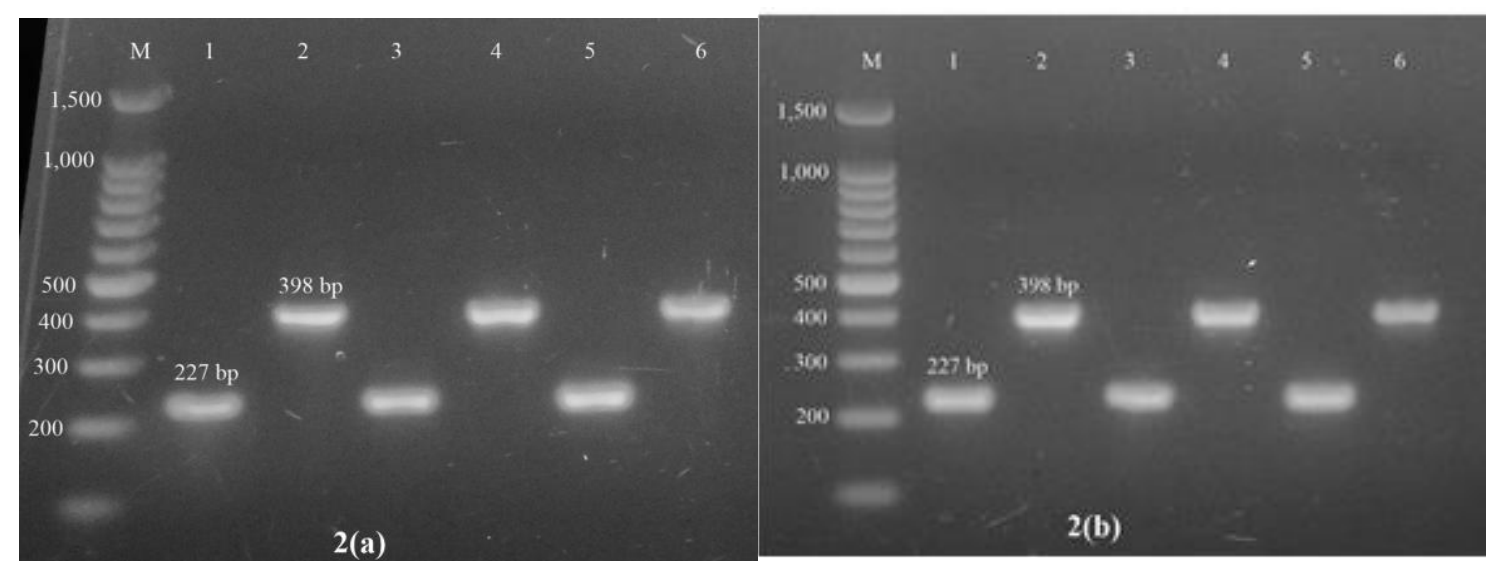

Figure 2 Species-specific simplex-PCR of cył b gene fragments of chicken (227 bp) and pork (398 bp) from raw meat mixtures extracted using 2(a) commercial extraction kit and 2(b) PCIA method. Lane 1 and 2:50\% chicken: 50\% pork; Lane 3 and 4: $90 \%$ chicken: 10\% pork; Lane 5 and 6: 99\% chicken: 1\% pork. Lane M, 100-bp DNA ladder

Pork contamination in beef is shown in Figure 3, in which DNA fragments of $274 \mathrm{bp}$ (cattle) and $398 \mathrm{bp}$ (pig) were detected. Lane 1 and 2 in both Figures $3(a)$ and $3(b)$ are beef contaminated with $50 \%$ pork, lane 3 , and 4 with $10 \%$ pork contamination and lane 5 and 6 contaminated with $1 \%$ pork.

Pork contamination can also be detected by up to $1 \%$ in the mixture without showing any significant decrease in band intensity. A study done by Ni'mah et al. [17] using commercial extraction kit, Genomic

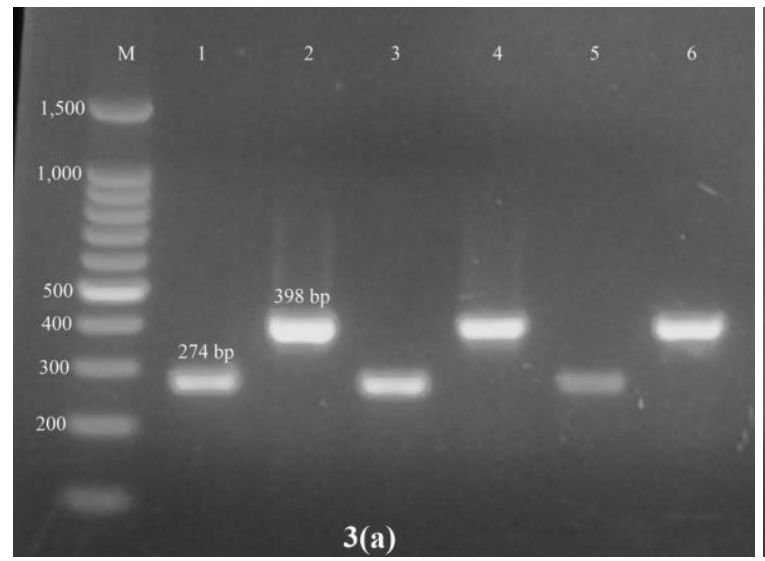

DNA Mini Kit, was also able to detect pork contamination in both fresh and cooked beef up to $1 \%$ of contamination. A study by Novianty et al. [18] has successfully identified pork contamination until the level of $1 \%$ in meatball. Samples were extracted using Quick-DNA Universal Kit. Both studies have performed PCR using species-specific primers to isolate mitochondrial cyt $b$ gene, and this showed that the cyt $b$ gene using the PCR method has high sensitivity to detect pork DNA.

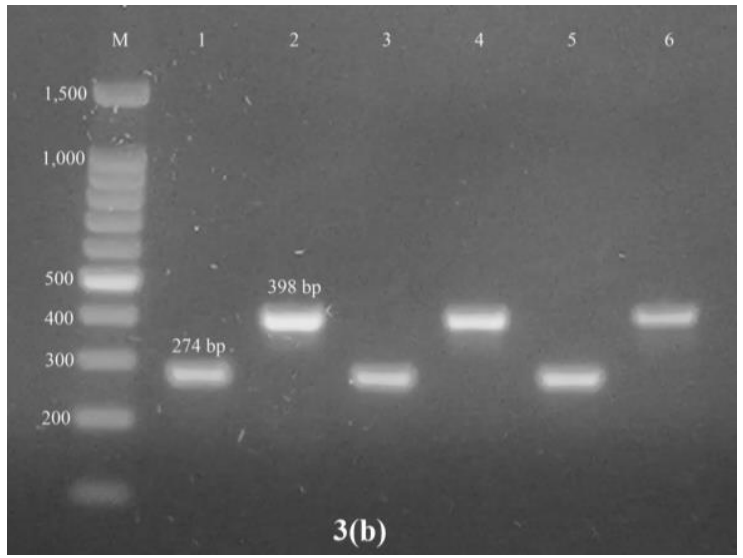

Figure 3 Species-specific simplex-PCR of cyt b gene fragments of beef (274 bp) and pork (398 bp) from raw meat mixtures extracted using 3(a) commercial extraction kit and 3(b) PCIA method. Lane 1 and 2: 50\% beef: 50\% pork; Lane 3 and 4: $90 \%$ beef: 10\% pork; Lane 5 and 6: $99 \%$ beef: 1\% pork. Lane M, 100-bp DNA ladder

In this study, samples extracted using the conventional PCIA method have shown an equal quality of results as with samples extracted using commercial kits, where up to $1 \%$ of contamination can still be detected. With an estimated cost of USD1.5 to USD2.0 compared to USD5 to USD6 when using a commercial kit, the conventional PCIA method is recommended as a cheaper alternative for extracting adulterated raw meat as commercial kit cost two to three times higher than the conventional.
According to Montowska \& Pospiech [19], meat adulterations denote not just as replacement of ingredients but also to incorrect information concerning the origin of raw materials and most frequently by cheaper meat species. For instance, beef adulterated with pork is often done by butchers merely for the benefit of gaining extra profit because pork is cheaper than beef [20]. Differentiating these mixed meats just by visual inspection is no easy task; therefore, a very effective identification method for 
meat species identification should be continuously developed and improved.

\subsection{CONCLUSION}

From this study, the conventional PCIA extraction method was confirmed to be able to produce high concentrations and purity DNA extracts. It can be recommended as a cost-effective alternative to extract meat products that are suspected to be adulterated as the porcine DNA can be detected as low as $1 \%$ in the beef and chicken mixtures. The application of species-specific primers consists of common forward, and one target species reverse primer has proven to be a reliable method in meat authentication. However, continuous improvement can be carried out by comparing the conventional $\mathrm{PCIA}$ method with more commercial kits available in the market.

\section{Acknowledgment}

This research is fully supported by UNIMAS internal grant (Tun Openg Chair), F07/TOC/1740/2018. The authors fully acknowledged the Ministry of Higher Education (MOHE) and Universiti Malaysia Sarawak for the approved fund, which makes this vital research viable and effective.

\section{References}

[1] Mohammad Nor, N. A. A., and Rosali, M. H. 2015. The Development and Future Direction of Malaysia's Livestock Industry. FFTC Agricultural Policy Articles. FFTC Agricultural Policy Platform Website: http://ap.fftc.agnet.org/ap_db.php?id=529\&print=1.

[2] Rahmati, S., Muhd Julkapli, N., A. Yehye, W., and Basirun, W. J. 2016. Identification of Meat Origin in Food Products A Review. Food Control 68: 379-390 DOI: https://dx.doi.org/10.1016/j.foodcont.2016.04.013.

[3] Salahudin, A., Ramli, M. A., Zulkepli, M. I. S., and Abd Razak, M. I. 2017. Issues in Halal Meat Product and Authentication Technology from Islamic Perspectives. International Journal of Academic Research in Business and Social Sciences. 7(12): 1305-1315 DOI: $10.6007 /$ IJARBSS/V7-i12/3768.

[4] Nakyinsige, K., Man, Y. B., and Sazili, A. Q. 2012. Halal Authenticity Issues in Meat and Meat Products. Meat Science. 91(3): 207-214.

[5] Ali, M. E., Kashif, M., Uddin, K., Hashim, U., Mustafa, S. and Che Man, Y. B. 2012. Species Authentication Methods in Foods and Feeds: The Present, Past, and Future of Halal Forensics. Food Analytical Methods. 5: 935-955

DOI: 10.1007/s12161-011-9357-3.

[6] Ha, J., Kim, S., Lee, J., Lee, S., Lee, H., Choi, Y., Oh, H., and Yoon, Y. 2017. Identification of Pork Adulteration in Processed Meat Products using the Developed Mitochondrial DNA-Based Primers. Korean Journal for Food Science of Animal Resources. 37(3): 464-468 DOI: https://doi.org/10.5851/kosfa.2017.37.3.464.

[7] Bhat, M. M., Mantoo, I. A., Salahuddin, M., Adil, S., and Pal, M. A. 2016. Meat Adulteration in Cooked Mutton Kebab with Cattle and Buffalo Meat and Its Detection using Mitochondrial DNA (mtDNA) Based Multiplex PCR. Asian Journal of Animal and Veterinary Advances. 11: 505-510. DOI: 10.3923/ajava.2016.505.510.

[8] Aida, A. A., Che Man, Y. B., C. M. V. L., Raha, A. R., and Son, R. 2005. Analysis of Raw Meats and Fats using Polymerase Chain Reaction for Halal Authentication. Meat Science. 69: 47-52

[9] Murugaiah, C., Noor, Z. M., Mastakim, M., Bilung, L. M., Selamat, J., and Radu, S. 2009. Meat Species Identification and Halal Authentication Analysis Using Mitochondrial DNA. Meat Science. 83: 57-61.

[10] Tanabe, S., Miyauchi, E, Muneshige, A., Mio, K., Sato, C. and Sato, M. 2007. PCR Method of Detecting Pork in Foods for Verifying Allergen Labeling and for Identifying Hidden Pork Ingredients in Processed Foods. Bioscience, Biotechnology, and Biochemistry. 71 (7): 1663-1667. DOI: $10.1271 / \mathrm{bbb} .70075$.

[11] Auricchio, B., Anniballi, F., Fiore, A., Skiby, J. E., and De Medici, D. 2013. Evaluation of DNA Extraction Methods Suitable for PCR-Based Detection and Genotyping of Clostridium Botulinum. Biosecurity and Bioterrorism: Biodefense Strategy, Practice, and Science. 11(1): 200206.

[12] Djurkin Kusec, I., Radisic, Z., Komlenic, M., and Kusec, G. 2015. Comparison of Commercial DNA Kits and Traditional DNA Extraction Procedure in PCR Detection of Pork in Dry/Fermented Sausages. Poljoprivreda. 21/1 Supplement): 199-202.

[13] Santos, André Luís F., Oliveira, Carolina Q. P., Arruda, Geovana Nicole P. N., \& Martins, John Kenned. 2018. Comparison of DNA Extraction Using Proteinase $K$ and Extraction Kit: Analysis of the Quality of the Genetic Material. Jornal Brasileiro de Patologia e Medicina Laboratorial. 54(2): 70-75.

DOI: https://dx.doi.org/10.5935/1676-2444.20180013.

[14] Sajali, N., Sie, C. W., Hanapi, U. K., Abu Bakar @ Jamaluddin, S., Tasrip, N. A., and Mohd Desa, M. N. 2018. The Challenges of DNA Extraction in Different Assorted Food Matrices: A Review. Journal of Food Sciences. 83(10): 2409-2414.

[15] Matsunaga, T., Chikuni, K., Tanabe, R., Muroya, S., Shibata K., Yamada, J., and Shinmura, Y. 1999. A Quick and Simple Method for the Identification of Meat Species and Meat Products by PCR Assay. Meat Science. 51: 143-148.

[16] Ozsensoy, Y. and Sahin, S. 2016. Comparison of Different DNA Isolation Methods and Use of Dodecyl Trimethyl Ammonium Bromide (DTAB) for the Isolation of DNA from Meat Products. Journal of Advanced Veterinary and Animal Research. 3(4): 368-374.

[17] Ni'mah, A., Kartikasari, Y., Pratama, A. D., Kartikasari, L. R. Hertanto, B. S., and Cahyadi, M. 2016. Detection of Pork Contamination in Fresh and Cooked Beef using Genetic Marker Mitochondrial-DNA Cytochrome B by Duplex-PCR. Journal of the Indonesian Tropical Animal Agriculture. $41(1): 7-12$.

[18] Novianty, E., Kartikasari, L. R., Lee, J. H., and Cahyadi, M. 2017. Identification of Pork Contamination in Meatball using Genetic Marker Mitochondrial DNA Cytochrome b Gene by Duplex-PCR. IOP Conf. Series: Materials Science and Engineering 193: 012002. DOI: 10.1088/1757-899X/193/1/012002.

[19] Montowska, M., and Pospiech, E. 2011. Authenticity Determination of Meat and Meat Products on the Protein and DNA Basis. Food Reviews International. 27: 84-100. DOI: $10.1080 / 87559129.2010 .518297$

[20] Chaobo, X., Feng, G., Pingya, W., Jin, Z., and Yuanyuan, L. (2017). Development and Utility of a Tri-Primer PCR for Simultaneous Detection of Cattle, Sheep, and Pig in Meat Products. International Food Research Journal. 24(1): 159163 